\title{
STUDY THE ROLE PLAYED BY FUNGAL GROWTH IN THE DETERIORATION OF LIME MORTARS, AN EXAMPLE FROM TUNISIA
}

\author{
Moussa, A. ${ }^{1}$, Mansour, M. ${ }^{1} \&$ Ayed, N. ${ }^{2}$ \\ ${ }^{1}$ Lecturer in Conservation dept., Faculty of Archaeology, Cairo Univ., Giza, Egypt \\ ${ }^{2}$ Prof. in Chemistry dept, Institut des Sciences Appliquees et de Technologie BP676/1080 Tunis
}

e-mail:dr_abubakr@msn.com

\begin{abstract}
In this study, mortars from the citadel of Nabeul where studied using XRD in order to identify their composition, and where investigated biologically to determine the role played by microorganisms in there decay. Calcium carbonate (calcite - lime) is the main component of the studied mortars; calcium silicate was also detected in addition to quartz and iron oxides. The biological investigation detected some fungal flora amongst: Aspergillus ochraceus, Aspergillus tamareii, Ascosphaera apis, Eurotium repens, Eurotium chevalieri, Doratomyces sp and Cladosporium cladosprioides.
\end{abstract}

Keywords: Nabeul, Biological Investigation, Lime mortars, Fungi, Biocorrosion

\section{Introduction}

The Nabeul governorate is located northeast Tunisia at $36^{\circ} 27^{\prime} \mathrm{N}$ and $10^{\circ} 44^{\prime}$ E. Nabeul city was constructed in the $5^{\text {th }}$ century B.C by the Greeks of Cyrene, serving as a trade port. Its name is an Arabised from the Greek Neapolis "new city". Kelibia is the third city in Nabeul governorate; it was constructed by the Carthaginians as the fortified town of Aspis in the $5^{\text {th }}$ century BC. The main landmark of Kelibia is its recently-

\section{Materials and methods}

The mortars used in the citadel of Kelibia were sampled for laboratory analyses to determine their chemical composition. X-ray diffraction (XRD) analysis was performed using powdered samples of the pigment materials and plasters using a Philips (PW1840) diffractometer with $\mathrm{Ni}$-filtered $\mathrm{Cu}-\mathrm{K \alpha}$ radiation. The samples were scanned over restored fort which overlooks the harbor. This fort dates back to the Roman age; it was built on a high hard rock formation about 150 ASL, the fort was enlarged by the Byzantines during the $6^{\text {th }}$ century AD. This paper aims to determine the type of mortars used as a building material in the fort, moreover assessing the role played by microorganisms in the decay of these mortars.

the $5-70^{\circ} 2 \theta$ intervals at a scanning speed of $1.2^{\circ} \mathrm{min}^{-1}$. A quantitative estimate of the abundance of the mineral phases was derived from the XRD data using the intensity of certain reflections and external standard mixtures of minerals compared to the JCPDS standards of 1967 [1]. The detection limits of the method were \pm 1 w/w $\%$. Samples were 
taken for mycological analyses by swabbing surfaces with sterile cotton swabs. The samples were then stored at $4^{\circ} \mathrm{C}$. Swab samples were diluted in $10 \mathrm{ml}$ sterile distillated water and shaken mechanically for 10 minutes. Petri -dish containing (M40Y; 400g sucrose, 20g Molt extract, 5g Yeast extract, 20g Agar Difco PDA Each sample was repeated in

\section{Results}

\subsection{XRD analyses}

Based on the XRD analyses; the first mortar sample which represents the collating mortar of the red brick in the citadel of Kelibia, composes of $50 \%$ calcite, $35 \%$ quartz, $9 \%$ orthoclase and $6 \%$ gypsum. The second sample, which was derived from the remains of the red pigmented plasters upon the citadel walls, composes of $68 \%$ quartz, $21 \%$ calcite, 8 $\%$ hematite and $3 \%$ orthoclase. The third XRD sample which represents a mortar sample with red and yellowish aggregates, which was derived from the eastern outer wall of the citadel,

\subsection{Biological investigation}

The biological investigation of the genera isolated from the lime mortar samples that were derived from the forte of Kelibia revealed that the fungal flora Aspergillus ochraceus represents the dominant fungi constituting (100\%) of the total fungal isolates from the collating mortar of the red brick, fig. (1). Aspergillus tamareii was detected upon the red pigmented plaster remains in the citadel walls, fig. (2). The fungal flora Ascosphaera apis, fig. (3). has been detected upon the mortar sample with red

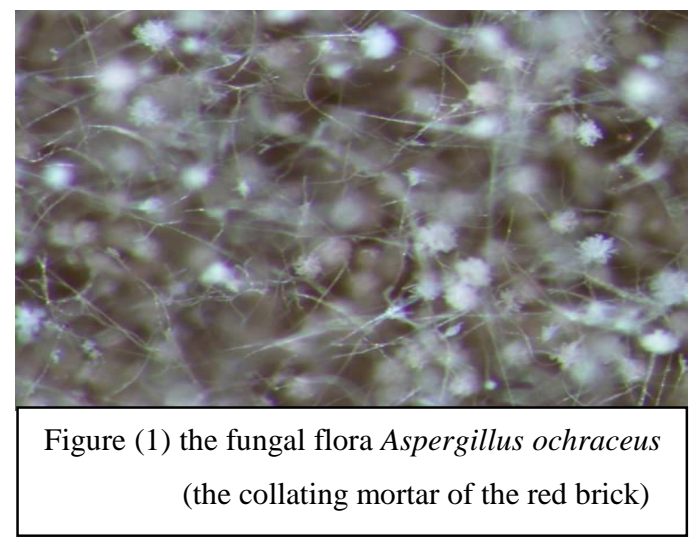

triplicate All the cultures were grown 7 days in thermostat at $24^{\circ} \mathrm{C}$. Macroscopic characteristics of the obtained isolates were examined. The fungi were identified by Olympus microscope (SZ*16) at the laboratory of Fungal and L broth; $1 \%$ tryptone, $0.5 \%$ yeast extract, $0.5 \% \mathrm{NaCl}$, ph 7.0.

composes of $54 \%$ quartz, $38 \%$ calcite, 6 $\%$ hematite and $2 \%$ halite. The fourth sample which represents the collating mortar of the wall mosaic in the archaeological site contains; $35 \%$ quartz, $25 \%$ calcium silicate, $24 \%$ calcite, $10 \%$ gypsum and $6 \%$ iron oxides (hematite and goethite). The last sample which represents the collating mortar of the ground mosaic inside the archaeological site composes of; $56 \%$ calcite, $37 \%$ quartz and $7 \%$ iron oxides (hematite and goethite).

and yellowish aggregates, which was derived from the eastern outer wall of the citadel, while the fungal flora Eurotium repens, fig. (4), and Eurotium chevalieri, fig. (5), were detected in the isolates taken from the collating mortar of the wall mosaic in the archaeological site. The isolates taken from the collating mortar of the ground mosaic inside the archaeological site have shown the presence of the fungal flora Doratomyces $s p$, fig. (6) and the fungal flora Cladosporium cladosprioides.

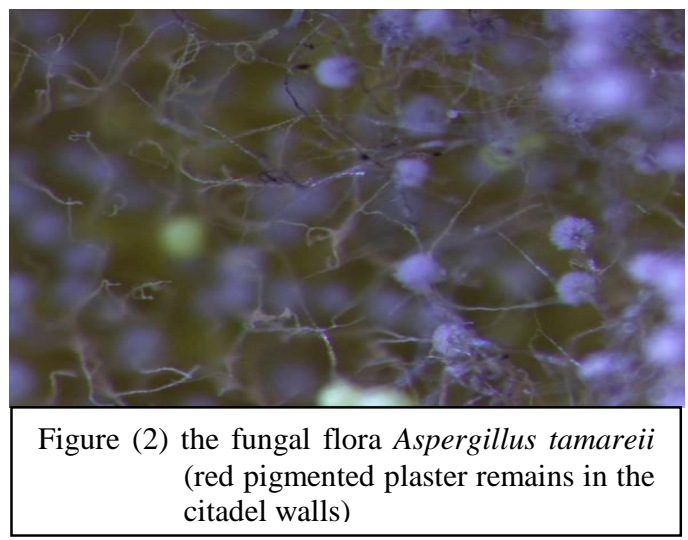



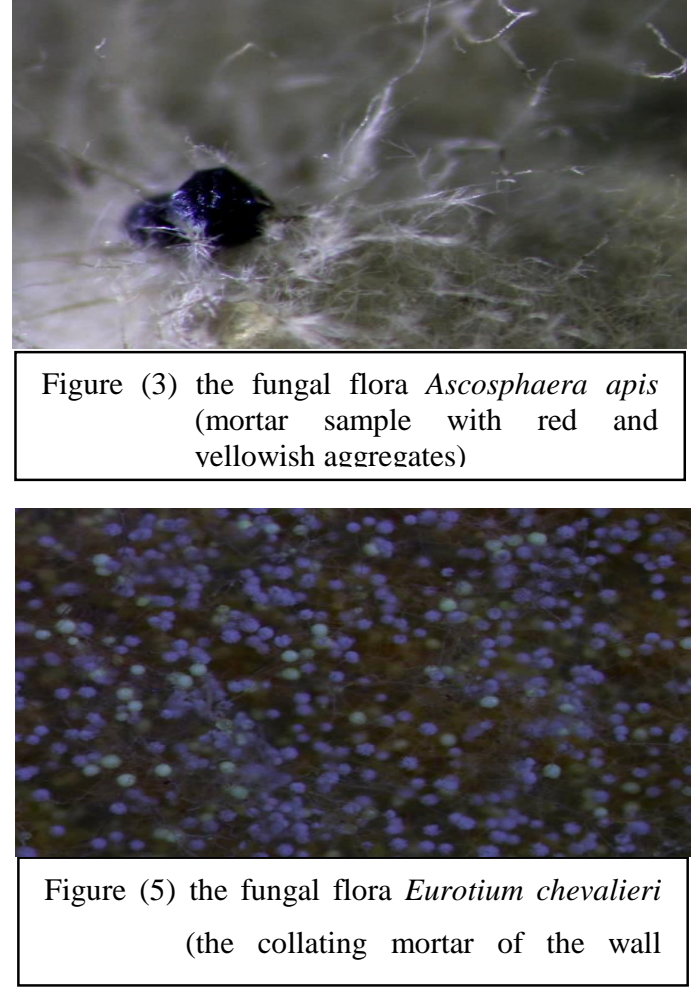

\section{Discussion}

The XRD analyses indicated that lime mortar is the basic mortar used in the fort of Kelibia, the samples contain different ratio of lime mixed with sand and other aggregates amongst: red brick fragments, pottery fragments, and other orthoclase compounds. Lime mortars can be given hydraulic properties by adding pozzolanic materials containing reactive silicates and aluminates. Romans made use of brick dust and volcanic ash. Many limes used in the past naturally had slightly hydraulic properties because they were made from limestone containing clay with reactive silicates and/or aluminates, It should be noted, for example, that not all brick dusts are pozzolanic. Recent research has shown that the most reactive brick dusts are obtained from low-fired bricks (fired at temperature below $900^{\circ} \mathrm{C}$ ) which are crushed to produce particles smaller than

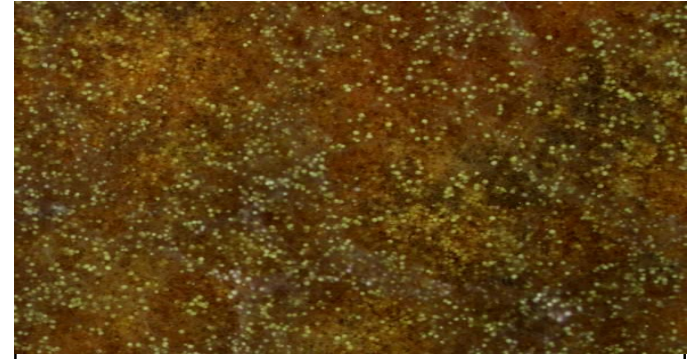

Figure (4) the fungal flora Eurotium repens (the collating mortar of the wall mosaic)

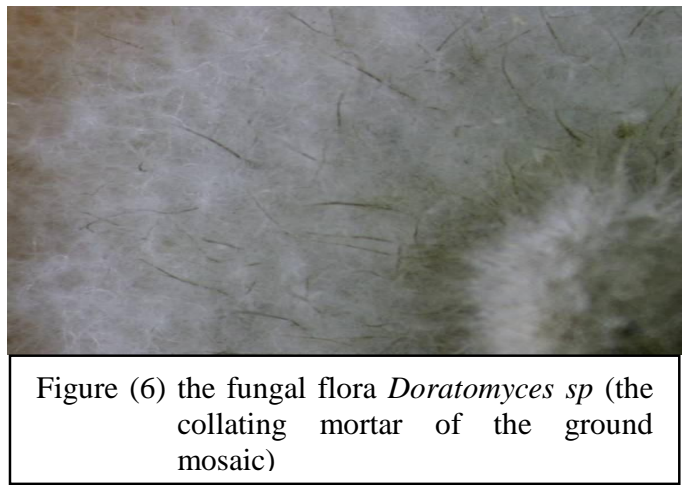

75 microns [2][3]. In Venice, the powder of crushed brick as artificial pozzolan has been widely used. The Romans used it to replace natural volcanic pozzolan where it was not available as it was near Rome [4]. In our case study that can be emphasized by the presence of calcium silicate in the fourth sample, and it also explains the presence of red and yellowish aggregates in some samples. Gypsum was found abreast with lime in some mortar samples, two destructive expansive reactions are usually taking place in the presence of gypsum leading to the formation of ettringite and thaumasite. The latter forms in historic mortars and plasters by the reaction of gypsum and calcium aluminum hydrates in a moist condition [5]. The formation of ettringite or thaumasite leads to the complete destruction of the material [6], as showing in following reaction.

$$
\begin{gathered}
3\left(\mathrm{CaSO}_{4} \cdot 2 \mathrm{H}_{2} \mathrm{O}\right)+3 \mathrm{CaO} \cdot \mathrm{Al}_{2} \mathrm{O}_{3} \cdot 6 \mathrm{H}_{2} \mathrm{O}+20 \mathrm{H}_{2} \mathrm{O} \rightarrow \underset{ }{3 \mathrm{CaO} \cdot \mathrm{Al}_{2} \mathrm{O}_{3} \cdot 3 \mathrm{CaSO}_{4} \cdot 32 \mathrm{H}_{2} \mathrm{O}} \\
(\text { Ettringite) }(1) \\
\mathrm{CaSO}_{4} \cdot 2 \mathrm{H}_{2} \mathrm{O}+\mathrm{CaCO}_{3}+\mathrm{CaSiO}_{3} \cdot \mathrm{H}_{2} \mathrm{O}+12 \mathrm{H}_{2} \mathrm{O} \rightarrow \underset{\mathrm{CaSiO}_{3} \cdot \mathrm{CaSO}_{4} \cdot \mathrm{CaCO}_{3} \cdot 15 \mathrm{H}_{2} \mathrm{O}}{\text { (Thaumasite) }(2)}
\end{gathered}
$$


The biological investigation proved that lime mortars in the studied object are exposed to the attack of microorganisms. Gettens and coworkers were among the first to point out, in 1941, that paintings could be "defaced or destroyed by the growth of those small, parasitical plants commonly called 'mold' or 'mildew' [7]. An important role is played by the microscopic fungi in atmosphere-exposed environment. The problem of longevity increase of archaeological buildings can be solved only with deep understanding of the kinetics and microscopic mechanisms of deterioration. As it is known from other inorganic materials (stones, mortars, plasters and pigments) a due attention should be given to interactions of a material with microorganisms and to the processes of their microbial degradation [8]. All surfaces may act as substrata for bacterial adhesion and biofilm formation and microbial attack on materials can take place either directly or indirectly, depending on the specific microorganism, biology, chemistry, physical properties of the materials and their environment [9]. Biocorrosion can occur through the excretion of organic acids by chemoorganothrophic microorganisms, including fungi and lichens. Those acids can also chelate metal cations, e.g. (Al, $\mathrm{Ca}, \mathrm{Fe}, \mathrm{Mg}, \mathrm{Mn}, \mathrm{Si}$ ) from minerals to form stable complexes [10]. The organisms associated with biodeterioration processes on buildings grow as biofilms containing a complex community of microorganisms, particulates and a high percentage of water, forming, under suitable moisture conditions, a gelatinous film [11]. Fungi prefer the acidic media $(5.5 \mathrm{pH})$, their growth starts when relative humidity in the surroundings reaches $65 \%$ with a temperature degree of $20-25^{\circ} \mathrm{C}$, fungi are very active at $80 \%$ R.H. They are Polly cellular, parasitic, saprophytic, and Heterotrophic creatures use C, O, N, S, $\mathrm{K}, \mathrm{Mg}, \mathrm{Zn}, \mathrm{Cu}$ and $\mathrm{Ca}$ as nutrients. Some natural pigments can withstand the fungal growth upon them like Goethite
"Limonite" $\mathrm{FeO}(\mathrm{OH})$, while they can grow on Malachite and hematite [12] [13]. Mural paintings rely on techniques in which pigments are suspended in water or oil, often in the presence of binders such as casein, egg yolk, animal glue and milk, and applied on the damp lime plaster. The calcium carbonate formed on contact with air consolidates the pigments. Thus, frescoes contain mainly inorganic components but the microbial flora colonizes these substrates easily [14]. The presence of significant amounts of carbonate compounds (e.g.,>3\% w/w $\mathrm{CaCO}_{3}$ ) in calcareous sandstones or lime mortars, results in the buffering of biogenic metabolic products producing a constant suitable $\mathrm{pH}$-milieu for the growth of bacteria. For example, mortar or cement repairs in masonry structures made of silicate-based stones favor microbial contamination of the previously unaffected rock material. Mortars containing significant amounts of weathering-prone minerals (i.e., feldspars, clays and ferruginous minerals, $>5 \% \mathrm{w} / \mathrm{v}$ ) are particularly susceptible to the development of microorganisms. Even digenetic organic residues in sedimentary stones can be considered as possible nutrient sources for the stoneinhabiting micro flora. The degree of contamination will depend on the pore size distribution as well as on the alkalinity of the mortar. They are particularly evident at interfaces between alkaline mortar and acidic siliceous stone material, or in cement repairs of stone, due to the $\mathrm{pH}$-gradients developed there [15]. Organic compounds presented in wall paintings are further increased by those that may be added at later times during retouching, restoration or relining or when a mural painting is detached and transferred to a canvas or a board. In some cases, extensive fungal colonization was reported even with frescoes that, after cleaning and consolidation, were removed from walls and transferred to a fiberglass support [16]. Soluble nylon coatings which widely used in conservation and restoration of 
Romanesque wall paintings, these products, despite their name, are insoluble compounds not easily removed by physical and chemical treatments. Furthermore, it must be noted that bacteria was detected on the wall paintings treated with this products [17]. Even polymers are potential substrates for heterotrophic microorganisms including bacteria and fungi [18] [19]. Biodeterioration is usually linked to environmental conditions, for example, moisture, temperature and light. Air pollution has, to some extent, influenced the colonization and growth pattern of microorganisms in polluted urban environments. Similarly buried soils are a dynamic natural habitat for microorganisms, invertebrates and roots; accordingly, soil organisms play key roles in maintaining soil structure as well as influencing decomposition. There is an intricate relationship between the physicochemical conditions, and the biological communities in soils [20]. Growth of microorganisms on paintings may cause aesthetic and structural damage. As aesthetic damage: pigment discoloration, stains, and formation of a biofilms on the painted surface, whereas structural damage: cracking and disintegration of paint layers, formation of paint blisters, and degradation of support polymers or of glues and binders resulting in detachment of the paint layer from the support. The two types of damage are strongly linked, and in the long run, structural damage profoundly affects the aesthetic quality of a painting. Conversely, aesthetic damage may precede serious injuries to the materials, for instance, in fungal colonization of mural paintings [20]. In a rare case, a biological growth was detected by Petersen, et. al. [21], between the lime wash layers in the over painting phenomenon, the distribution of microorganisms has been tied to relative humidity more than nutrients. SaizJimenez and Samson -in their study of biodeterioration on a Spanish frescohave shown that, at the beginning, growth of fungi on a mural's surface caused only aesthetic damage since there was little or no alteration of the painted surface. Later on, fungal growth in depth occurred. Hyphae penetrated the painted layer, degrading some of its components (especially glues and binders), which resulted in a decrease in the cohesion of the painted layers, thus giving rise to exfoliations, cracking, and loss of the paint. The damages inflicted by metabolites, often acidic in nature, and by extra-cellular enzymes excreted by microorganisms should be added to these damages [22]. These compounds may modify the colors as well as the stability of the painted layer and of the substrate.

\section{Conclusion}

Based on the results of both XRD and biological analyses, it has been concluded that mortar used in the fort of Kelibia-Tunisia are all lime mortars mixed with sand in different ratios. $A$ small percentage of gypsum was added to some lime mortars in the studied object for strengthen purposes, crushed pottery and crushed brick were used as aggregates with lime mortars for giving them hydraulic properties. Halite was also detected in some samples but its presence refers to the location of the fort on the Tunisian cost. All lime mortars in the studied object are exposed to the attack of microorganisms and fungal growth.

\section{References}

[1] JCPDS, (1967). Jaint committee on powder diffraction standards, index to the powder diffraction file, American society for testing and materials, Pennsylvania

[2] British Standards Institution, (2000). Code of Practice for Cleaning and
Surface Repair of Buildings (82212:2000), BSI, London

[3] Maurenbrecher, A., (2004). Mortars for repair of traditional masonry: the ASCE practice periodical on structural design and construction, National research council, Ottawa, Canada, pp: 62-65. 
[4] Collepardi, M., (2004). Historical review of development of chemical and mineral admixtures for use in stucco plaster and terrazzo floor, Rome.

[5] Böke, H. \& Akkurt, S., (2003). Ettringite formation in historic bath brick-lime plasters, Cement and Concrete Research, Vol. 33, pp: 1457-1464.

[6] Van Balen, K., Toumbakari, E., BlancoVarela, M., Aguilera, J., Puertas, F., Palomo, A., Sabbioni, C., Riontino, C. \& Zappia, G., (1999). Environmental deterioration of ancient and modern hydraulic mortars, Research Report XX, European commission protection and conservation of European Cultural Heritage (EDAMM), pp: 1-194.

[7] Gettens, R., Pease, M. \& Stout, G., (1941). The problem of mold growth in paintings, Technical Studies in Fine Arts, Vol. 9, pp: 127-143.

[8] Kondratyeva, I., Gorbushina, A., Boikova, A., (2006). Biodeterioration of construction materials, Glass Physics and Chemistry, Vol. 32 (2), pp: 254-256.

[9] Gu, J., \& Mitchell, R., (2006). The Prokaryotes, Vol. 1, Symbiotic Associations, Biotechnology, Applied Microbiology.

[10] Fernandes, P., (2006). Applied microbiology and biotechnology in the Conservation of Stone Cultural Heritage Materials, Mini Review, Applied Microbiological Biotechnology, Vol. 73, pp: 291-296.

[11] Kiel, G. \& Gaylarde, C., (2007). Diversity of salt-tolerant culturable aerobic microorganisms on historic buildings in Southern Brazil, World Journal of Microbiological Biotechnology, Vol. 23, pp: 363-366.

[12] Sorlini, C., Sacchi, M. \& Ferrari, A., (1987). Microbiological deterioration of Gamabara's frescoes exposed to open air in Brescia, Italy, International Biodeterioration, Vol. 23 (3), pp: 167179.

[13] Wiedemann, H., Reller, A. \& Lamprecht, I., (1996). Investigation on the influence of some ancient pigments on the growth of Lichens as artifactdeterioration agents: in Realini, M., \& Toniolo, L., (Eds), $2^{\text {nd }}$ International symposium on the oxalate films in the conservation of works of art, Milan, Italy, pp: 353-358.
[14] Piñar, G. \& Lubitz, W., (2002). Molecular techniques: Aplication to the analysis of microbial communities colonising art works and to the monitoring of changes. Case study: Wall Paintings of the Castle of Herberstein, Vienna, Austria.

[15] Warscheid, Th. \& Braams, J., (2000). Biodeterioration of stone: a review, International Biodeterioration \& Biodegradation, Vol. 46, pp: 343-368.

[16] Ciferri, O., (1999). Microbial degradation of paintings, Applied and Environmental Microbiology, Vol. 65 (3), pp: 879-885.

[17] Urzi, C., (1999). On microbes and art: the role of microbial communities in the Degradation and Protection of Cultural Heritage, Environmental Microbiology, Vol. 1 (6), pp: 551-553.

[18] Gu, J., (2003) Microbiological deterioration and degradation of synthetic polymeric materials: Recent research advances, in International Biodeterioration \& Biodegradation, Vol. 52, pp: 69-91.

[19] Szaraz, L., \& Beczner, J., (2003). Optimization processes of a $\mathrm{CO}_{2}$ measurement set-up for assessing biodegradability of polymer, International Biodeterioration \& Biodegradation, Vol. 52, pp: 93-95.

[20] Cassar, M., (2001). Technological requirements for solutions in the conservation and protection of historic monuments and archaeological remains, European parliament, directorate general for research, a "STOA Programme", Final report, Luxembourg,

[21] Petersen, K., Yun., Y. \& Krumbien, W., (1995). On the occurrence of alkalito lerant and alkaliphilic microorganisms on wall paintings and their interaction in restoration, consolidation: in Araynak, C., \& Singhasiri, C., (Eds), Proceedings of the $3^{\text {rd }}$ international conference on biodeterioration of cultural properties, Thailand, pp: 371-386.

[22] Saiz-Jimenez, C. \& Samson, R., (1981). Biodegradacion de obras de arte, hongos implicados en la degradacion de los frescos del monasterio de la Rabida (Huelva), Botanica Macaronesica, Vol. 9, pp: 255-264. 